\title{
МІЖНАРОДНІ СТРАТЕГІЇ ЕКОНОМІЧНОГО РОЗВИТКУ ТА ОСОБЛИВОСТІ РОЗВИТКУ УКРАЇНИ
}

В статті розглянуто стратегії розвитку країн, що розвиваються: концепція «порочного кола бідності», концепція переходу до самопідтримуючого зростання, концепція «великого поштовху» та їі різновиди. Проаналізовано основні макроекономічні показники, що характеризують рівень економічного розвитку. Визначено, що Україна, будучи однією 3 найбільших за територією та кількістю населення держав Європи, є однією 3 найбідніших, а дотримання неокласичних постулатів економічної теорії на початку 90-х років 20 століття не допомогло подолати структурну кризу. Визначено, що активізація ефективного інвестування та створення відповідного інституціонального середовища могли створити підґрунтя для економічного розвитку. Зазначено, що в умовах сповільнення глобалізаційних процесів, викликаних розповсюдженням COVID-19, формування стратегії економічного розвитку України повинно базуватись на засадах індустріалізації економіки та неопротекціонізму.

Ключові слова: стратегії економічного розвитку; COVID-19; неопротекціонізм; стратегія; інвестиції; інновації.

Постановка проблеми. Для країн, що здійснюють реформування національних економік в напрямку створення соціально-ефективних ринкових систем, важливим питанням залишається адаптація кращої світової практики при формуванні власних стратегій. Стратегія економічного розвитку країни $\epsilon$ складовою ланцюга, основою якого $€$ панівна або переважаюча у певний часовий період економічна(i) теорія(ï) та, на основі якої визначається оптимальна модель економічного розвитку країни. Стратегія економічного розвитку ґрунтується на притаманній даній країні моделі економічного розвитку. Кожна модель економічного розвитку не $є$ чимось усталеним на тривалий час. Залежноі від домінуючих тенденцій світового чи національного економічного розвитку моделі зближуються за своїм змістом. Спільним у моделях розвинутих держав $€$ те, що механізмом їх дії $€$ розвинута економіка ринкового типу. Водночас вони відрізняються деякими рисами економічних відносин, що ґрунтуються на інституціональних 
особливостях розвитку конкретної країни.

Не дивлячись на різноманіття досліджених наукових проблем, присвячених стратегіям економічного розвитку країни, багато питань щодо особливостей розвитку національної економіки й на цей час залишаються невирішеними у теоретичному аспекті. Значна увага наразі прикута до формування стратегії економічного розвитку в умовах вимушеної самоізоляції країн, викликаної розповсюдженням гострої респіраторного захворювання COVID-19, звуження (корекції) глобалізаційних тенденцій. Потребують глибшої теоретичної розробки питання вибору стратегії економічного розвитку Україною, чинників економічного зростання, шляхів активізації процесу розвитку економіки в умовах сповільнення інтеграційних процесів. Усі ці обставини визначили вибір теми статті, їі логіку та структуру.

Аналіз останніх досліджень і публікацій. Проблеми економічного розвитку та обрання відповідної стратегії знаходять своє відображення в багатьох наукових публікаціях. Це пов'язано 3 технічним та технологічним оновленням, стратегією держави, яка орієнтована на інноваційний розвиток та забезпечення економічної безпеки. Фундаментальні дослідження, присвячені вивченню цих питань, знайшли відображення в роботах 3. Варналія, В. Гейця, Я. Жаліла, Г. Зінгера, Р. Нурксе, А. Хіршмана та інших учених.

Постановка завдання. Метою дослідження $\epsilon$ наукове обґрунтування та розробка теоретико-методологічних питань вибору стратегії економічного розвитку України в умовах сповільнення інтеграційних та глобалізаційних процесів, викликаних розповсюдженням гострого респіраторного захворювання COVID-19.

Виклад основного матеріалу. Розвиток національної економіки неможливий без стратегічного бачення іï місця у світовому співтоваристві та шляху його досягнення. Після здобуття незалежності перехід до економічної системи ринкового типу вимагав реалізації кардинально інших принципів економічної діяльності. Україна отримала значні стартові можливості та ресурси після розпаду СРСР і здобуття незалежності - розвинений промисловий сектор, енергетичну та транспортну інфраструктуру, що відповідали потребам національної економіки. Проте сьогодні через відсутність стимулів до модернізації та далекоглядної політики значна частина транспортної інфраструктури, енергетики, електричних та газових мереж перебувають у критичному стані, а експорт країни на 54 відсотки складається 3 товарів 3 низькою доданою вартістю [1]. У 90-ті роки XX століття відбувалась повільна інституалізація нової, адекватної вимогам ринку, економічної 
системи. Проте обрання екстенсивного типу економічного зростання, сировинної експортної орієнтації, монополізації та олігархізації економіки стало причиною важкого та повільного відновлення економіки після світової фінансової кризи 2008-2009 років. Тимчасова окупація AP Крим та частини Луганської і Донецької областей з 2014 року, практично знищення їх донедавна потужного виробничого потенціалу, як не парадоксально, проте стали причиною кардинальної перебудови інституціональної структури, яка була б здатна реалізовувати національні інтереси та протидіяти загрозам та небезпекам зовнішнього та внутрішнього характеру. Екстернальний негативний шок наприкінці 2019 року, пов'язаний 3 розповсюдженням гострого респіраторного захворювання COVID-19, також вніс свої корективи у формування візії шляху забезпечення економічного розвитку.

Суттєвим фактором економічного зростання наразі $\epsilon$ активізація інвестиційної діяльності внутрішніх і зовнішніх економічних агентів. У макроекономічному аспекті інвестиційна діяльність $€$ процесом формування майбутнього економіки країни. Загалом, зростання інвестицій в поточному періоді призводить до зростання виробництва у майбутньому, проте нестача інвестиційних ресурсів на макрорівні призводить до економічної відсталості країни, наслідком чого стає потрапляння у так зване «порочне коло бідності». При всій абстрактності теорії «порочного кола бідності» звертає на себе увагу той факт, що багато дослідників акцентує увагу на небезпеку зниження середнього доходу на одну особу [2]. Так, в результаті високих темпів зростання населення і повільних - ВВП, відбувається зниження ВВП на одну особу. Динаміка валового внутрішнього продукту на одну особу за ПКС в дол. США та темпи приросту реального ВВП представлені в табл. 1.

Таблиця 1

Динаміка макроекономічних показників

\begin{tabular}{|l|l|l|l|l|l|}
\hline \multicolumn{1}{|c|}{ Показники } & \multicolumn{5}{|c|}{ Роки } \\
\hline & $\mathbf{1 9 9 7}$ & $\mathbf{1 9 9 8}$ & $\mathbf{1 9 9 9}$ & $\mathbf{2 0 0 0}$ & $\mathbf{2 0 0 1}$ \\
\hline $\begin{array}{l}\text { ВВП на одну особу за ПКС } \\
\text { (дол. США) }\end{array}$ & 3670,9 & 3674,4 & 3755,2 & 4106,8 & 4631,6 \\
\hline $\begin{array}{l}\text { Темп приросту ВВП на одну } \\
\text { особу за ПКС (дол. США) (\%) }\end{array}$ & $-0,42$ & 0,09 & 2,20 & 9,36 & 12,78 \\
\hline $\begin{array}{l}\text { Темп приросту реального } \\
\text { ВВП (\%) }\end{array}$ & $-3,0$ & $-1,9$ & $-0,2$ & 5,9 & 9,2 \\
\hline $\begin{array}{l}\text { Темп приросту населення } \\
\text { (\%) }\end{array}$ & $-0,93$ & $-0,89$ & $-0,94$ & $-1,00$ & $-1,05$ \\
\hline
\end{tabular}


продовження табл. 1

\begin{tabular}{|c|c|c|c|c|c|}
\hline \multirow[t]{2}{*}{ Показники } & \multicolumn{5}{|c|}{ Роки } \\
\hline & 2002 & 2003 & 2004 & 2005 & 2006 \\
\hline $\begin{array}{l}\text { ВВП на одну особу за ПКС } \\
\text { (дол. США) }\end{array}$ & 4999,1 & 5621,9 & 6521,6 & 6977,3 & 7775,6 \\
\hline $\begin{array}{l}\text { Темп приросту ВВП на одну } \\
\text { особу за ПКС (дол. США) } \\
\text { (\%) }\end{array}$ & 7,93 & 12,46 & 16,00 & 6,99 & 11,44 \\
\hline $\begin{array}{l}\text { Темп приросту реального } \\
\text { ВВП (\%) }\end{array}$ & 5,2 & 9,4 & 12,1 & 2,7 & 7,3 \\
\hline \multirow[t]{2}{*}{$\begin{array}{l}\text { Темп приросту населення } \\
(\%)\end{array}$} & $-0,95$ & $-0,81$ & $-0,76$ & $-0,73$ & $-0,67$ \\
\hline & 2007 & 2008 & 2009 & 2010 & 2011 \\
\hline $\begin{array}{l}\text { ВВП на одну особу за ПКС } \\
\text { (дол. США) }\end{array}$ & 8642,2 & 9062,2 & 7818,3 & 8245,4 & 8909,7 \\
\hline $\begin{array}{l}\text { Темп приросту ВВП на одну } \\
\text { особу за ПКС (дол. США) } \\
(\%)\end{array}$ & 11,15 & 4,86 & $-13,73$ & 5,46 & 8,06 \\
\hline $\begin{array}{l}\text { Темп приросту реального } \\
\text { ВВП (\%) }\end{array}$ & 7,9 & 2,3 & $-14,8$ & 4,2 & 5,5 \\
\hline \multirow[t]{2}{*}{$\begin{array}{l}\text { Темп приросту населення } \\
(\%)\end{array}$} & $-0,60$ & $-0,54$ & $-0,44$ & $-0,40$ & $-0,36$ \\
\hline & 2012 & 2013 & 2014 & 2015 & 2016 \\
\hline $\begin{array}{l}\text { ВВП на одну особу за ПКС } \\
\text { (дол. США) }\end{array}$ & 9343,3 & 10691,8 & 10743,6 & 10164,3 & 11148,2 \\
\hline $\begin{array}{l}\text { Темп приросту ВВП на одну } \\
\text { особу за ПКС (дол. США) } \\
(\%)\end{array}$ & 4,87 & 14,43 & 0,48 & $-5,39$ & 9,68 \\
\hline $\begin{array}{l}\text { Темп приросту реального } \\
\text { ВВП (\%) }\end{array}$ & 0,2 & 0,0 & $-6,6$ & $-9,8$ & 2,3 \\
\hline \multirow[t]{2}{*}{$\begin{array}{l}\text { Темп приросту населення } \\
(\%)\end{array}$} & $-0,25$ & $-0,23$ & $-5,47$ & $-0,36$ & $-0,40$ \\
\hline & 2017 & 2018 & 2019 & 2020 & 2021* \\
\hline $\begin{array}{l}\text { ВВП на одну особу за ПКС } \\
\text { (дол. США) }\end{array}$ & 11871,1 & 12634,2 & 13350,5 & 13056,7 & д/в \\
\hline $\begin{array}{l}\text { Темп приросту ВВП на одну } \\
\text { особу за ПКС (дол. США) } \\
\text { (\%) }\end{array}$ & 6,48 & 6,43 & 5,67 & $-2,20$ & д/в \\
\hline $\begin{array}{l}\text { Темп приросту реального } \\
\text { ВВП (\%) }\end{array}$ & 2,4 & 3,5 & 3,2 & $-4,0$ & $-2,2$ \\
\hline $\begin{array}{l}\text { Темп приросту населення } \\
\text { (\%) }\end{array}$ & $-0,44$ & $-0,51$ & $-0,57$ & $-0,67$ & д/в \\
\hline
\end{tabular}

* - дані за 1 квартал

д/в - дані відсутні

Джерело: за даними Світового банку та Державної служби статистики України [3; 4; 5]. 
Основним фактором економічного зростання багатьма економічними школами в тій чи іншій мірі розглядалися інвестиції за умов їх достатнього обсягу, зосередження у високотехнологічних галузях та при відповідному державному стимулюванні [6]. На думку американського вченого Р.Нурксе, брак капіталу (інвестицій) призводить до низької продуктивності праці, що обумовлює, в свою чергу, низький рівень доходів. Звідси - слабка купівельна спроможність і, як наслідок, недостатній стимул до інвестування. В умовах обмеженості заощаджень і відсутність інтересу до капіталовкладень нестача капіталу відтворюється як типова риса цього суспільства (рисунок). 3 іншого боку, причиною низької продуктивності праці, а отже, і причиною деградації економіки ряд дослідників називають інституційні умови, зокрема низька кваліфікація робочої сили і нерозвиненість систем освіти і професійної підготовки.

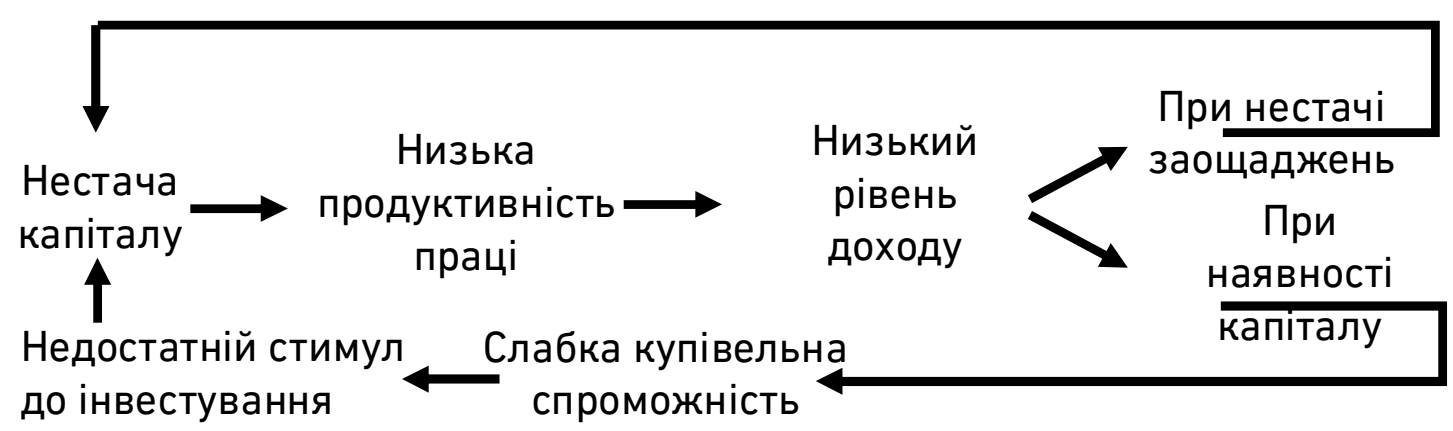

Джерело [7].

Рисунок. Порочне коло нестачі капіталу

Порочне коло бідності, а отже, і низький рівень доходу (ВВП), відповідно до кейнсіанського тлумачення $€$ наслідком низького рівня споживання та заощаджень:

$$
C \downarrow S \downarrow \Rightarrow A D \downarrow \Rightarrow Q \downarrow \Rightarrow \Delta I \downarrow \Rightarrow p^{\prime} \downarrow \Rightarrow \Delta Q \downarrow \Rightarrow Y \downarrow .
$$

Скорочення споживання $(C \downarrow)$ зменшує величину агрегованого попиту $(A D \downarrow)$, який спричиняє скорочення виробництва $(Q \downarrow)$ та низьких темпів зростання інвестиції ( $\Delta I \downarrow)$, а вони, зі свого боку, призводять до низької ефективності виробництва, низького рівня прибутковості ( $\left.p^{\prime} \downarrow\right)$ та, як наслідок, низьким стимулам до зростання виробництва ( $\Delta Q \downarrow)$, що, врешті-решт, пояснює зменшення доходу.

Крім економічних чинників соціально-економічного розвитку, представники різних економічних шкіл відзначали залежність економічних складових розвитку від інших неекономічних чинників. До таких відносили рівень інтелектуального розвитку людства, демографічний чинник, рівень свободи, дотримання законів, рівень 
захисту прав власності, етичність принципів, ідеологія, ефективність економічних, правових і політичних інститутів.

Так, факт політичної нестабільності чинить вплив на самовідтворення порочного кола бідності, адже за умов нестабільного політичного режиму існує висока небезпека порушення прав власності, націоналізації приватних підприємств, обмеження репатріації прибутків тощо. Все це різко підвищує трансакційні витрати економічних агентів, не сприяє залученню в країну іноземних інвестицій, з одного боку, і збільшує темпи втечі національного капіталу за кордон, 3 іншого. Низькі темпи заощадження позначаються на зниженні темпів інвестування, що призводить до стагнації. Зростання бідності та загострення соціальних конфліктів, в свою чергу, створює сприятливий ґрунт для розквіту популізму, основаному на вкрай лівих (або правих) ідеях, створює загрозу для різких політичних змін, з усіма негативними наслідками, що випливають з них.

Багато з цих рис є типовими для сучасної України, яка вже довгий час перебуває у порочному колі бідності. Серед усіх країн за показником ВВП на одну особу за ПКС (у дол. США) за даними Світового банку у 2020 р. Україна має показник - 13057 дол. США [3], що менше за середньосвітовий показник на 24\% (17109,4 дол. США). Сусідами ж України є Вірменія, Шрі-Ланка, Іран, Парагвай та Молдова, серед європейських країн позиція України знаходиться на третьому з кінця місці (останнє - Косово з 11367,9 дол. США), а серед країн СНД наша позиція вища за Молдову, Узбекистан, Киргизію та Таджикистан.

Логічним продовженням теорії «порочного кола бідності» стала концепція переходу до самопідтримуючого зростання, яку теоретично обґрунтував У.Ростоу. Основна ідея цієї концепції полягала в обгрунтуванні переходу від традиційного суспільства до сучасного суспільства західного типу. У. Ростоу запропонував виділяти 6 стадій зростання [8]: 1) традиційне суспільство (the traditional society); 2) період створення передумов для зльоту (the preconditions for take-off); 3) зліт (the take-off); 4) рух до зрілості (the drive to maturity); 5) епоха високого масового споживання (the age of high mass consumption); 6) стадія пошуку якості життя.

Як зазначав Ростоу, для того, щоб зростання стало автоматичним, самопідтримуючим, необхідно виконання умов, які можна дещо адаптувати і до сучасних умов:

1. різке збільшення частки виробничих інвестицій в національному доході (мова йде не тільки про величину, але і про 
якість інвестицій);

2. стрімкий розвиток одного або декількох секторів промисловості (відповідно до сучасних умов, це може бути не тільки промисловість, а й сектор послуг, зокрема ІТ-сектор);

3. політична перемога прихильників модернізації економіки над захисниками традиційного суспільства (точніше захисниками статусу-кво: монополізованої, сировинноорієнтованої економіки) [9].

Виникнення осередків нової інституціональної структури мало забезпечити, на думку У. Ростоу, поширення початкового імпульсу зростання на всю економічну систему (шляхом мобілізації капіталу 3 внутрішніх джерел, залучення зовнішніх джерел, реінвестування прибутків тощо).

Незважаючи на очевидні для багатьох економістів недоліки, концепція переходу до «самопідтримуючого зростання» дуже вплинула на лідерів «третього світу» і була використана в процесі створення нових теорій модернізації - концепцій «великого поштовху» (big push). У центрі досліджень теорій «великого поштовху» головна увага приділялася ролі автономних інвестицій, обумовлених економічною політикою держави, спрямованої на зростання національного доходу.

Як зазначали дослідники (Р. Харрод, О. Домар) для модернізації країн, що розвиваються, необхідно значне вливання капіталу, в результаті чого почнеться самопідтримувальне зростання. Мобілізувати такі ресурси на добровільній основі було нереально, тому акцент робився на активне втручання держави через заходи фіскальної та монетарної політики для активізації ефективного попиту, а у разі їх неефективності - на залучення іноземних інвестицій.

Розвиток, відповідно до теорій «великого поштовху», розуміється як глибокі структурні зміни, що охоплюють основні галузі народного господарства. Як тоді, так і тепер відсутність сучасних галузей народного господарства сприймається як головне гальмо розвитку, тому індустріалізації та створенню набору сучасних галузей приділяється першочергове значення. До різновидів теорії «великого поштовху» відносять концепції «збалансованого набору інвестицій» Р. Нурксе [10], «незбалансованого зростання» А. Хіршмана [11] та «збалансованого зростання за допомогою незбалансованих інвестицій»Г. Зінгера [12].

Серед вітчизняних економістів, які досліджували розвиток економічної системи, слід відзначити М. Туган-Барановського, який стверджував, що «у капіталістичному господарстві нагромадження капіталу створює постійно тенденцію до розширення виробництва. 
Капітал постійно тисне на виробництво, намагаючись рухати його вперед» [13]. Варто відмітити, що рушійною силою еволюції капіталістичної системи господарювання він вважав інновації, насамперед у галузях, що виробляють засоби виробництва. Важливим методологічним відкриттям був висновок, що досягнення технологічної вичерпаності діючими виробництвами спричиняють як кризову фазу економіки, так і відповідне обмеження процесів інвестування та накопичення вільного позичкового капіталу. Інвесторам стає невигідним процес розширеного відтворювання в діючих галузях i тому фінансові ресурси починають нагромаджуватись у грошовій формі як позичковий капітал та шукати собі нове застосування.

Представники інноваційних теорій розвитку А.Шпітгоф та Й. Шумпетер намагались розкрити питання щодо того, в які види основного капіталу інвестується вільний грошовий капітал в епоху бурхливого розвитку.

А. Шпітгоф доповнив теорію М. Туган-Барановського механізмом заповнення через комерціалізацію науково-технічних досягнень інвестиційного вакууму, що утворюється у кризовій фазі циклу. Принциповим положенням теорії Й. Шумпетера, яке відрізняє ії від теорії А. Шпітгофа, є висновок про те, що нове, як правило, не виростає із старого, а з'являється поруч із старим, витісняє його i змінює всі відносини таким чином, що виникає необхідність у специфічному процесі «розміщення». Тому «піднесенню» передує структурна перебудова, а наступний розвиток - це не просто продовження попереднього, а новий розвиток, який породжується іншими умовами і почасти іншими людьми.

Важливим в теорії Й. Шумпетера $€$ пояснення причини, чому нові виробництва і відповідно підприємці-новатори з'являються не безперервно, а відразу у великій кількості («кластером»). Причина у тому, що поява нових виробництв взаємопов'язана і цей зв'язок зумовлюється тим, що прорив нового спочатку здійснюється невеликою кількістю підприємців-новаторів, які володіють особливим талантом бачення і реалізації нових шляхів, а також силою характеру для подолання могутньої протидії інерції традицій. Поява одного чи кількох таких підприємців полегшує появу інших, які, в свою чергу, сприяють появі наступних. Й. Шумпетер вважав, що підприємець-новатор як такий не «знаходить» і не «створює» нових можливостей. Останні існують самі по собі, нагромаджуються і навіть пропагуються пресою. Але без підприємця вони не можуть реалізуватися, тому функція його якраз і полягає виключно в тому, 
щоб реалізувати їх $[14$, C. 206].

У 2007 році лауреат Нобелівської премії Е. Фелпс конкретно охарактеризував умови високої динаміки розвитку економіки - окрім нових комерційних ідей, потрібні:

- достатня кількість підприємців 3 діапазоном можливостей трансформувати їх в кінцевий продукт, попри існування бар'єрів;

- фінансисти (бізнес-ангели, венчурні фонди) для того, щоб відсутність фінансів не відштовхнула нові ідеї;

- неспокійні менеджери, які постійно повинні бути на сторожі нових методів в освіті, та споживачі, які здатні азартно купувати та використовувати нову продукцію [15, С. 25].

3 еволюційної точки зору, економічний розвиток в будь-якій соціально-економічній системі необхідно вважати нерівноважним процесом, у якому залучені господарюючі суб'єкти використовують технології різних поколінь. Якщо у розвинених країн нові технології виникають внаслідок появи нових винаходів, то в країнах, що розвиваються - в результаті їх запозичення у перших країн. На думку ще одного Лауреата Нобелівської премії Е. Прескота [16], країна, що розвивається, може наздогнати провідні промислові країни лише тоді, коли ліквідує обмеження у спроможності використовувати технології. Якщо, з одного боку, є зрозумілість того, що потрібно змінювати в країні, то з іншого боку, незрозуміло, чи буде політична воля для здійснення відповідних реформ.

Отже, в умовах сповільнення інтеграційних та глобалізаційних процесів, викликаних розповсюдженням гострого респіраторного захворювання COVID-19, формування стратегії економічного розвитку України повинно базуватись на засадах індустріалізації економіки та нового протекціонізму. Якщо механізмом традиційного протекціонізму були мито, квоти та тарифи, то наразі основним механізмом захисту внутрішнього виробника $€$ внутрішні екологічні та технологічні норми та стандарти щодо продукту чи виробничого процесу, а саме різний їх рівень в різних країнах. Негармонізованість стандартів призводить до того, що виробники у країнах 3 більш низьким рівнем стандартів будуть більш конкурентоспроможними внаслідок нижчих витрат на виробництво у деяких галузях порівняно з виробниками у країнах з високим рівнем стандартів.

Висновки. Україна є однією з найбільших за територією та кількістю населення держав Європи, але також однією 3 найбідніших. Україна посідає лише 88 місце у світі за показником ВВП на душу населення Україна. За результатами 30-річного регулювання економіки України так і не вдалося реалізувати 
потенціал у природних ресурсах, географічному положенні та якості людського капіталу. Загальне розуміння тенденції розвитку економіки України - недовикористання базових факторів виробництва: праця, земля, капітал [17]. Крім того, відставання від країн Центральної і Східної Європи можна пояснити і відмінностями в умовах здатності генерувати нові та імпортувати існуючі передові технологічні знання. В цьому випадку мова йде також про різні неекономічні детермінанти, які впливають на економічний розвиток - інституційні особливості: свобода, дотримання законів, етичні принципи економічної діяльності, ідеологія тощо. В умовах сповільнення глобалізаційних процесів, викликаних розповсюдженням COVID-19, формування стратегії економічного розвитку України повинно базуватись на засадах індустріалізації економіки та нового протекціонізму.

1. Про затвердження Національної економічної стратегії на період до 2030 року : Постанова Кабінету Міністрів України від 3 березня 2021 р. № 179. URL: https://www.kmu.gov.ua/npas/pro-zatverdzhennya-nacionalnoyi-eko-a179. (дата звернення: 30.05.2021). 2. Нуреев Р. М. Экономика развития: модели становления и модернизации рыночной экономики : учеб. пособ. М. : Норма, 2008. 367 с. 3. Світовий банк. Індикатори. URL: http://databank.worldbank.org/data/reports.aspx?source=world-developmentindicators\#advancedDownloadOptions (дата звернення: 30.05.2021). 4. Темп приросту реального ВВП. Державна служба статистики України. URL: http://ukrstat.gov.ua/ (дата звернення: 30.05.2021). 5. Середньорічна чисельність населення. Державна служба статистики України. URL: http://database.ukrcensus.gov.ua/ (дата звернення: 30.05.2021). 6. Baran P. A. The Political Economy of Growth. New Delhi. 1962. 7. Nurkse R. Problems of Capital Formation in Underdevelopment Countries. Oxford. 1955. P. 5. 8. Rostow W.W. Theory of Economics Growth from David Hume to the Present. With Perspective to the Next Century. N.Y. : Oxford University Press, 1992. 9. Нікитенко Д. В. Інвестиційна безпека України: сутність та інституціональне забезпечення : монографія. Рівне: НУВГП, 2018. 376 с. 10. Nurkse R. Equilibrium and Growth in the World Economy. Cambridge, 1961. 11. Hirschman A. The Strategy of Economic Development. 1958. 12. Singer H. International Development. Growth and Trade, 1964. 13. Туган-Барановский М.И. Промышленные кризисы в современной Англии, их причины и влияние на народную жизнь. Спб., 1894. С. 175. 14. Бажал Ю. М. Актуальність ідей М. І. Туган-Барановського для теорії економічного розвитку. Михайло Іванович Туган-Барановський : особистість, творча спадщина і сучасність / під заг. ред. проф., д-ра екон. наук 0. О. Шубіна, проф., д-ра екон наук А. А. Садєкова ; МОН України, Донецький держ. ун-т економіки і торгівлі ім. М. Туган-Барановського. Донецьк : Каштан, 2007. С. 196-213. 15. Бова Т. В. Державна інноваційно-інвестиційна політика України: теорія, методологія, напрями розвитку: монографія. Донецьк: Юго-Восток, 2011. 452 с. 16. Prescott E. Economic Growth and Business Cycles, with T. F. Cooley, Chapter 1 in T. F. Cooley, ed., Frontiers of Business Cycle Research, (Princeton University Press, 1995). 1-38. 17. Nikytenko D. Theoretical view on the problem of economic development of Ukraine. Science and education: trends and prospects : Collection of scientific articles. Ascona 
Publishing, New York : United States of America, 2018. P. 57-64.

\section{REFERENCES:}

1. Pro zatverdzhennia Natsionalnoi ekonomichnoi stratehii na period do 2030 roku : Postanova Kabinetu Ministriv Ukrainy vid 3 bereznia 2021 r. № 179 . URL: https://www.kmu.gov.ua/npas/pro-zatverdzhennya-nacionalnoyi-eko-a179. (data zvernennia: 30.05.2021). 2. Nureev R. M. Ekonomika razvitiya: modeli stanovleniya i modernizatsii ryinochnoy ekonomiki : ucheb. posob. M. : Norma, 2008. 367 s. 3. Svitovyi bank. Indykatory. URL: http://databank.worldbank.org/data/reports.aspx?source=worlddevelopment-indicators\#advancedDownloadOptions (data zvernennia: 30.05.2021). 4. Temp pryrostu realnoho VVP. Derzhavna sluzhba statystyky Ukrainy. URL: http://ukrstat.gov.ua/ (data zvernennia: 30.05.2021). 5. Serednorichna chyselnist naselennia. Derzhavna sluzhba statystyky Ukrainy. URL: http://database.ukrcensus.gov.ua/ (data zvernennia: 30.05.2021). 6. Baran P.A. 1962. The Political Economy of Growth. New Delhi. 7. Nurkse R., 1955. Problems of Capital Formation in Underdevelopment Countries. Oxford. P. 5. 8. Rostow W.W. Theory of Economics Growth from David Hume to the Present. With Perspective to the Next Century. N.Y. : Oxford University Press, 1992. 9. Nikytenko D. V. Investytsiina bezpeka Ukrainy: sutnist ta instytutsionalne zabezpechennia : monohrafiia. Rivne : NUVHP, 2018. 376 s. 10. Nurkse R. Equilibrium and Growth in the World Economy. Cambridge, 1961. 11. Hirschman A. The Strategy of Economic Development. 1958. 12. Singer H. International Development. Growth and Trade, 1964. 13. Tugan-Baranovskiy M. I. Promyshlennyie krizisy v sovremennoi Anglii, ih prichinyi i vliyanie na narodnuyu jizn. Spb., 1894. S. 175. 14. Bazhal Yu. M. Aktualnist idei M. I. Tuhan-Baranovskoho dlia teorii ekonomichnoho rozvytku. Mykhailo Ivanovych Tuhan-Baranovskyi : osobystist, tvorcha spadshchyna i suchasnist / pid zah. red. prof., d-ra ekon. nauk 0. 0. Shubina, prof., d-ra ekon nauk A. A. Sadiekova ; MON Ukrainy, Donetskyi derzh. un-t ekonomiky i torhivli im. M. Tuhan-Baranovskoho. Donetsk : Kashtan, 2007. S. 196-213. 15. Bova T. V. Derzhavna innovatsiino-investytsiina polityka Ukrainy: teoriia, metodolohiia, napriamy rozvytku : monohrafiia. Donetsk : Yuho-Vostok, 2011. 452 s. 16. Prescott E. Economic Growth and Business Cycles, with T. F. Cooley, Chapter 1 in T. F. Cooley, ed., Frontiers of Business Cycle Research, (Princeton University Press, 1995). 1-38. 17. Nikytenko D. Theoretical view on the problem of economic development of Ukraine. Science and education: trends and prospects: Collection of scientific articles. Ascona Publishing, New York : United States of America, 2018. P. 57-64.

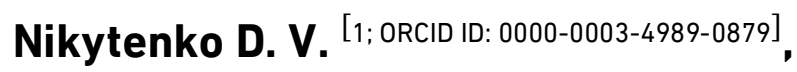
Doctor of Economics, Professor

${ }^{1}$ National University of Water and Environmental Engineering, Rivne

\section{INTERNATIONAL STRATEGIES OF ECONOMIC DEVELOPMENT AND FEATURES OF UKRAINE'S DEVELOPMENT}

For countries that are reforming national economies in the direction of creating socially efficient market systems, an important issue remains the adaptation of best international practices in the formation of their own strategies. A significant factor in economic growth now is the intensification 
of investment activities of domestic and foreign economic agents. In the macroeconomic aspect, investment activity is a process of shaping the future of the country's economy.

The article considers the development strategies of developing countries: the concept of «vicious circle of poverty», the concept of transition to self-sustaining growth, the concept of «big push» and its varieties: the concept of «balanced investment», «unbalanced growth» and «balanced growth through unbalanced investments». Ukraine, being one of the largest countries in Europe in terms of territory and population, is one of the poorest. Adherence to the neoclassical postulates of economic theory in the early 90's of the 20th century did not help to get out of the structural crisis. In 2020, Ukraine ranks only 88th in the world in terms of GDP per capita. According to the results of $\mathbf{3 0}$ years of regulation of the Ukrainian economy, it has not been possible to realize the potential in natural resources, geographical location and quality of human capital. Considerable attention is currently paid to the formation of neoprotectionism, caused by the slowdown of globalization trends and the spread of acute respiratory disease COVID19.

The lag behind the countries of Central and Eastern Europe is explained not only by approaches to the transformation of the economic system, but also by differences in the ability to generate new and import existing advanced technological knowledge and institutions. In this case, we are also talking about various non-economic determinants that affect economic development - institutional features: freedom, observance of laws, ethical principles of economic activity, ideology, and so on. In the conditions of slowing down of globalization processes caused by the spread of COVID-19, the formation of the strategy of economic development of Ukraine should be based on the principles of industrialization of the economy and neoprotectionism.

Keywords: economic development strategies; COVID-19; neoprotectionism; strategy; investment; innovation.

Никитенко Д. В. [1; ORCID ID: 0000-0003-4989-0879], д.э.н., профессор

${ }^{1}$ Национальный университет водного хозяйства и природопользования, г. Ровно

\section{МЕЖДУНАРОДНЫЕ СТРАТЕГИИ ЭКОНОМИЧЕСКОГО РАЗВИТИЯ И ОСОБЕННОСТИ РАЗВИТИЯ УКРАИНЫ}

В статье рассмотрены стратегии развития развивающихся стран: концепция «порочного круга бедности», концепция перехода к самоподдерживающемуся росту, концепция «большого толчка» и ее разновидности. Проанализированы основные макроэкономические 
показатели, характеризующие уровень экономического развития. Определено, что Украина, будучи одной из крупнейших по территории и количеству населения государств Европы, является одной из самых бедных, а соблюдение неоклассических постулатов экономической теории в начале 90-х годов 20 века не помогло преодолеть структурный кризис. Определено, что активизация эффективного инвестирования и создания соответствующего институционального среды могли создать основу для экономического развития. Отмечено, что в условиях замедления глобализационных процессов, вызванных распространением COVID-19, формирования стратегии экономического развития Украины должно базироваться на принципах индустриализации экономики и неопротекционизма.

Ключевые слова: стратегии экономического развития; COVID-19; неопротекционизм; стратегия; инвестиции; инновации. 